\title{
Solar response in tropical stratospheric ozone: a 3-D chemical transport model study using ERA reanalyses
}

\author{
S. Dhomse ${ }^{1}$, M. P. Chipperfield ${ }^{1}$, W. Feng ${ }^{1}$, and J. D. Haigh ${ }^{2}$ \\ ${ }^{1}$ School of Earth and Environment, University of Leeds, LS2 9JT, UK \\ ${ }^{2}$ Blackett Laboratory, Imperial College, London, SW7 2AZ, UK \\ Received: 18 March 2011 - Published in Atmos. Chem. Phys. Discuss.: 6 May 2011 \\ Revised: 6 December 2011 - Accepted: 9 December 2011 - Published: 16 December 2011
}

\begin{abstract}
We have used an off-line 3-D chemical transport model (CTM) to investigate the 11-yr solar cycle response in tropical stratospheric ozone. The model is forced with European Centre for Medium-Range Weather Forecasts (ECMWF) (re)analysis (ERA-40/operational and ERAInterim) data for the 1979-2005 time period. We have compared the modelled solar response in ozone to observationbased data sets that are constructed using satellite instruments such as Total Ozone Mapping Spectrometer (TOMS), Solar Backscatter UltraViolet instrument (SBUV), Stratospheric Aerosol and Gas Experiment (SAGE) and Halogen Occultation Experiment (HALOE). A significant difference is seen between simulated and observed ozone during the 1980s, which is probably due to inhomogeneities in the ERA-40 reanalyses. In general, the model with ERAInterim dynamics shows better agreement with the observations from 1990 onwards than with ERA-40. Overall both standard model simulations are partially able to simulate a "double peak"-structured ozone solar response with a minimum around $30 \mathrm{~km}$, and these are in better agreement with HALOE than SAGE-corrected SBUV (SBUV/SAGE) or SAGE-based data sets. In the tropical lower stratosphere (TLS), the modelled solar response with time-varying aerosols is amplified through aliasing with a volcanic signal, as the model overestimates ozone loss during high aerosol loading years. However, the modelled solar response with fixed dynamics and constant aerosols shows a positive signal which is in better agreement with SBUV/SAGE and SAGE-based data sets in the TLS. Our model simulations suggests that photochemistry contributes to the ozone solar response in this region. The largest model-observation differences occur in the upper stratosphere where SBUV/SAGE and SAGE-based data show a significant (up to $4 \%$ ) solar
\end{abstract}

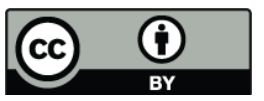

Correspondence to: S. Dhomse (s.dhomse@see.leeds.ac.uk) response whereas the standard model and HALOE do not. This is partly due to a positive solar response in the ECMWF upper stratospheric temperatures which reduces the modelled ozone signal. The large positive upper stratospheric solar response seen in SBUV/SAGE and SAGE-based data can be reproduced in model runs with fixed dynamical fields (i.e. no inter-annual meteorological changes). As these runs effectively assume no long-term temperature changes (solarinduced or otherwise), it should provide an upper limit of the ozone solar response. Overall, full quantification of the solar response in stratospheric ozone is limited by differences in the observed data sets and by uncertainties in the solar response in stratospheric temperatures.

\section{Introduction}

Quantifying the influence of solar flux variability on the Earth's climate is very important in order to understand past behaviour and to have confidence in predictions of its future evolution (e.g. Steinbrecht et al., 2004; Dhomse et al., 2006). Various mechanisms have been proposed and some are linked with changes in ozone concentration, based on the observation that the largest flux changes occur in the ultraviolet (UV) region (Haigh, 1994). These changes in UV flux can alter ozone production (and destruction) and, as ozone is a radiatively active gas, they can also modify atmospheric dynamics. For a recent review see Gray et al. (2010). However, such a quantification is difficult as stratospheric ozone concentrations are also influenced by various chemical and dynamical processes such as the Quasi-Biennial Oscillation (QBO), meridional circulation, aerosols, greenhouse gases and halogen loading (WMO, 2007). The strong coupling between these processes makes it quite challenging to separate the influence of any other individual process. Such a quantification depends on the quality of not only the ozone data, but also the other data sets used to separate the influence

Published by Copernicus Publications on behalf of the European Geosciences Union. 
of other individual processes. Among this the quality of the meteorological variables used to separate the dynamical influence are most critical.

A "double peak" structured solar response in stratospheric ozone is now widely accepted in the scientific community (WMO, 2011). There is also broad agreement that the upper stratospheric solar response is of photochemical origin. Various satellite and ground-based total ozone data also show a statistically significant solar response in total ozone (WMO, 2007). As lower stratospheric ozone is the main contributor to the total column ozone, the lower stratospheric response is largely responsible for the solar response in the total column. However, the origins of the mid-stratospheric minimum and lower stratospheric maximum in the solar response still remain as an open scientific issue. With the exception of McCormack et al. (2007), most of the published 2-D models show only one broad peak in solar response in the tropical middle stratosphere (e.g. Brasseur, 1993; Haigh, 1994). This deficiency in 2-D models is usually linked with difficulties in simulating dynamical feedback because these models have a simple parametrisation of eddy fluxes.

There is also fairly good evidence for a dynamical influence on the stratospheric solar response. For example, a QBO-dependent solar flux - high latitude temperature relationship is well established (Labitzke and van Loon, 1987; Labitzke, 2004). Ozone transport from the tropics to mid-high latitudes through the mean meridional (BrewerDobson) circulation is influenced by the QBO phase through the Holton-Tan mechanism (Holton and Tan, 1980). So, a stronger (weaker) meridional circulation increases (decreases) ozone transport from the tropics to mid-latitudes (Weber et al., 2003). On the other hand, Salby and Callaghan (2000) argued that the QBO itself varies with the solar cycle, so this can also modify the mean meridional as well as QBO-induced circulations in the stratosphere. At the same time the downward-propagating QBO transports midupper stratosphere ozone-rich air (along with other chemical species) into the tropical lower stratosphere (TLS) (Chipperfield et al., 1994), where ozone is long-lived and is under dynamical control.

Hence, various pathways have been suggested to explain this lower stratospheric solar response. Callis et al. (2001) suggested that this may be due to changes in nitrogen oxides $\left(\mathrm{NO}_{\mathrm{x}}\right)$ through energetic particles, but Hood and Soukharev (2006) showed that the effects of odd-nitrogen occur only at higher latitudes. Meanwhile, Kodera and Kuroda (2002) argued for a solar-induced weakening of the mean meridional circulation near solar maxima. They suggested that solar UV-induced enhancement of the lower mesospheric subtropical jet (LMSJ) leads to changes in planetary wave propagation and the strength of the meridional circulation. The net result for the tropical stratosphere is relatively less upwelling under solar maximum conditions. Matthes et al. (2004) could simulate this, although their modelled response in the lower stratosphere was much weaker than seen in the observations. In contrast, Dhomse et al. (2006) showed that the observed increase in northern hemispheric mid-high latitude total ozone during 1998-2003 (solar cycle 23) was due to the combined effect of solar cycle maximum and enhanced wave forcing during this period. Marsh and Garcia (2007) argued that the lower stratospheric solar response is an aliasing effect of El-Niño Southern-Oscillation or ENSO events, but Hood et al. (2010) showed that this mechanism is not supported by the observations. Lee and Smith (2003) proposed that the lower stratosphere ozone solar response may be due to the aliasing effect of the QBO and volcanic eruptions and Matthes et al. (2010) indicated the importance of the QBO for simulating this response correctly. However, Austin et al. (2008) found that a representation of the QBO in chemistryclimate models (CCMs) is not necessary in order to simulate the lower stratospheric peak, although they argued that varying sea surface temperatures (SSTs) were. On the other hand, Schmidt et al. (2010), could simulate a lower stratospheric peak in their CCM with fixed SSTs and no QBO. However, it is also important to note that although some of the CCMs used in above-mentioned studies are able to simulate a double-peak-structured solar response, the quality of the models' treatments of transport in the lower stratosphere has not been fully investigated. For example, the mean age-ofair and tropical upwelling from some of these models seems to be inconsistent (Austin et al., 2008; Butchart et al., 2011; Strahan et al., 2011).

Similarly, a double-peak-structured solar response is also observed in stratospheric temperature (Frame and Gray, 2010). And, as lower stratospheric ozone is positively correlated with temperature, Steinbrecht et al. (2003) found that the solar response patterns for total column ozone are very similar to those for $50 \mathrm{hPa}$ temperatures and have a similar seasonal dependence. Using a fixed dynamical heating (FDH) model and comparing results with ERA-40 and NCEP data, Gray et al. (2009) showed a double-peak solar response in tropical stratospheric temperatures. They showed that the solar irradiance change causes an increase of $1.6 \mathrm{~K}$ and $0.6 \mathrm{~K}$ in upper and lower stratospheric temperatures, respectively. Also, most of the stratospheric temperature studies show a significant positive solar response in upper stratospheric temperatures (e.g. Randel et al., 2009; Remsberg, 2009; Frame and Gray, 2010). Direct increases in UV flux can lead to direct increases in both ozone and temperature. Increases in ozone will also increase radiative heating. However, ozone and temperature are inversely correlated in the upper stratosphere and so this feedback will modify the apparent ozone solar response (Brasseur and Solomon, 1984, see also Fig. 2 from Dikty et al., 2010).

There is also an additional puzzle about the solar response in the stratosphere. Firstly, using the Solar Backscatter UltraViolet instrument (SBUV), Stratospheric Aerosol and Gas Experiment (SAGE) and Halogen Occultation Experiment (HALOE) data, the estimated solar response shown in Fig. 14 from Soukharev and Hood (2006) indicates a minimum solar 
response in the middle stratosphere with a larger response in the upper and lower stratosphere (see also Fig. 12 in Randel and Wu, 2007 and Fig. 3 in Tourpali et al., 2007). In contrast, using HALOE data (averaged between $25^{\circ} \mathrm{S}-25^{\circ} \mathrm{N}$ ) for the 1992-2005 time period, Remsberg (2008, Fig. 12) estimated a maximum solar response near $32-35 \mathrm{~km}$, which decreases in the upper stratosphere until $48 \mathrm{~km}$ and then increases above. Using SAGE II data for 1992-2005 without a trend term, Remsberg and Lingenfelser (2010, Fig. 15) showed that SAGE II and HALOE solar responses (averaged between $25^{\circ} \mathrm{S}-25^{\circ} \mathrm{N}$ ) are quite similar. However, it is also important to remember that both Remsberg (2008) and Remsberg and Lingenfelser (2010) use relatively short time series in their analysis.

Recently, Haigh et al. (2010) used daily solar spectrum measurements from the Spectral Irradiance Monitor (SIM) instrument on the Solar Radiation and Climate Experiment (SORCE) satellite to show a much larger decline in UV radiation than simple solar irradiance models predicted for the 2004-2007 time period. Using a photochemical model and Microwave Limb Sounder (MLS) data, they showed that these large spectral changes in UV led to a significant decrease in stratospheric ozone from 2004 to 2007, below an altitude of $45 \mathrm{~km}$, with an increase above this altitude. Although there are limited long-term high quality solar flux data, they argued for the possibility that the effects of solar variability on the atmosphere may be different than our present understanding. Using SORCE solar radiance data, the Whole Atmosphere Community Model (WACCM) and Sounding of the Atmosphere using Broadband Emission Radiometry (SABER) satellite instrument data, Merkel et al. (2011) showed an increase in ozone below $1 \mathrm{hPa}(\sim 48 \mathrm{~km})$ and a decrease in ozone above $0.01 \mathrm{hPa}(\sim 80 \mathrm{~km})$ for an active solar period (2002/2003) compared to a quiet one (2008/2009). However, SORCE, SABER and MLS data sets cover only 5 to $6 \mathrm{yr}$, so these results must be treated with caution.

Off-line three-dimensional (3-D) Chemical Transport Models (CTMs) are computationally inexpensive and can use analysed winds to specify the transport. In some ways these winds are more realistic than a CCM as they are tied to the real state of the atmosphere. On the other hand care is needed when using these winds for long-term studies, due to temporal changes in quality and availability of the observations used in the assimilation system (e.g. Feng et al., 2007; Monge-Sanz et al., 2007). Sekiyama et al. (2006) used a 3D CTM (MJ98-CTM) forced with dynamical fields from a General Circulation Model (GCM), assimilated with ERA40 winds at every time step, to study the solar response in the stratosphere. They showed that ozone changes are controlled by photochemistry in the upper stratosphere and by dynamics in the TLS, with the transition occurring between $10-30 \mathrm{hPa}(25-30 \mathrm{~km})$.

In this paper we use the SLIMCAT 3-D CTM, forced with European Centre for Medium-Range Weather Forecasts
(ECMWF) dynamical fields (ERA-40, ECMWF operational, and ERA-Interim) for a more detailed study to quantify the solar response in tropical ozone. We perform an updated analysis of the ozone profile solar response from two heightresolved satellite-based data sets: SAGE-corrected SBUV (SBUV/SAGE) data from McLinden et al. (2009) and SAGEbased data from Randel and Wu (2007). In particular, we investigate the modelled profile of the solar response in tropical ozone with observational data using correlation, composite and regression analysis. Section 2 describes our 3-D model and the experiments performed while Sect. 3 describes the satellite ozone data sets that we have used. The results of the model runs are described in Sect. 4 and our summary is given in Sect. 5.

\section{Model experiments}

We have used the SLIMCAT 3-D CTM with different meteorological forcing. A detailed description of the model can be found in Chipperfield (1999) and later updates in Chipperfield (2006). SLIMCAT has been extensively validated against various ground-based and satellite data sets as well used to study short-term and long-term ozone changes (e.g. Chipperfield and Jones, 1999; Sinnhuber et al., 2003; Rex et al., 2004; Chipperfield et al., 2005; Feng et al., 2007, 2011; Santee et al., 2008). Some of the key recent improvements relevant for this study are as follows. We have updated the representation of solar flux variability using monthly mean solar solar fluxes from Lean et al. (2001) for all 203 UVvisible spectral bands used in the photochemistry scheme. Reaction rates have been updated from Sander et al. (2006) and we have improved representation of the stratospheric aerosol loading using stratospheric aerosol data from Stratospheric Processes And their Role in Climate (SPARC, 2006).

In this study we use a model resolution of $5.6^{\circ} \times 5.6^{\circ}$ with $32 \sigma-\theta$ levels from the surface to $\sim 60 \mathrm{~km}$ and the experiments performed are summarised in Table 1. For run A_E40, the model was forced using meteorological fields from ECMWF (re)analyses (ERA-40 (1978-2001) and operational (2002-2005), Uppala et al., 2005). During February 2006 the ECMWF operational model underwent significant changes, so we restrict our analysis to the period ending in December 2005. The model does not use analysed vertical winds in the stratosphere but rather they are calculated using heating rates every time step. Run B_EI is similar to run A_E40 except ERA-Interim, dynamical fields are used for the 1989-2005 period. Run C_FIX uses one year of meteorology (fixed from 2004 using ECMWF operational analysis) repetitively for 27 yr. Run D_AFIX is similar to Run C_FIX, but uses constant monthly mean aerosol fields (mean for 1996-2005).

Key differences in ERA-Interim compared to ERA-40 are the use of 4-dimensional (4-D) data assimilation, increased horizontal resolution (T255), improved model physics and 
Table 1. Aerosol and dynamical conditions for the model simulations. All the runs use time-varying solar fluxes

\begin{tabular}{lll}
\hline Run & Aerosols & Dynamics \\
\hline A_E40 & Time-varying & ERA-40 + operational \\
B_EI & Time-varying & ERA-Interim \\
C_FIX & Time-varying & Perpetual 2004 (operational) \\
D_AFIX & Constant & Perpetual 2004 (operational) \\
\hline
\end{tabular}

humidity analysis. ERA-Interim also uses more satellite data, better quality control and variational bias correction. For details see Dee et al. (2011). For the stratosphere it uses reprocessed Global Ozone Monitoring Experiment (GOME) ozone profile data from 1995 onwards (http://www.ecmwf. int/).

\section{Satellite ozone data}

Here we use total ozone and ozone profile observations that are constructed using various satellite instrument data sets. For total ozone, we use the Total Ozone Mapping Spectrometer (TOMS) and SBUV merged (Revision 5) data set (Frith et al., 2004). These are monthly zonal mean total ozone values constructed by merging individual TOMS, SBUV/SBUV2 and OMI satellite observations (hereafter "TOMS/SBUV"). TOMS/SBUV data was obtained from http://acdb-ext.gsfc.nasa.gov/Data_services/merged/.

To estimate the solar response in the ozone profile, commonly used satellite data sets are SBUV, SAGE and HALOE. SBUV (SBUV and SBUV/2) are nadir viewing instruments on Nimbus-7 (SBUV, 1978-1990), NOAA-9 (SBUV/2, 1985-1998), NOAA-11 (SBUV/2, 1989-2003), NOAA-16 (SBUV/2, 2000-present) and NOAA-17 (SBUV/2, 2002present) satellite platforms. Retrieved ozone profiles are in volume mixing ratio (VMR) in pressure coordinates. Vertical resolution is $\sim 6 \mathrm{~km}$ near $3 \mathrm{hPa}$, degrading to $\sim 10 \mathrm{~km}$ at 1 and $20 \mathrm{hPa}$ (Bharthia et al., 2004). SAGE I (1979-1981), SAGE II (1984-2005) and HALOE (1991-2005) are solar occultation instruments on the Applications Explorer MissionB (AEM-B), Earth Radiation Budget Satellite (ERBS) and Upper Atmosphere Research Satellite (UARS), respectively. Retrieved ozone profiles from SAGE are in number density in height coordinates, whereas those from HALOE are in VMR in pressure coordinates coordinates. The vertical resolutions for SAGE and HALOE are less than $1 \mathrm{~km}$ and $2 \mathrm{~km}$, respectively (McCormick et al., 1989; Russell et al., 1993).

Due to different measurement techniques and retrieval algorithms, there are some well known errors and biases in these data sets when used for long-term analysis (Hassler et al., 2008; McLinden et al., 2009). In general, SBUV data are affected by drifts in various satellite platforms and low vertical resolution. For example, Nazaryan et al.
(2007) reported statistically significant biases in HALOE and SBUV/ 2 between 10 and $3 \mathrm{hPa}(30-40 \mathrm{~km})$. Terao and Logan (2007) noticed up to $50 \%$ difference in ozone trends between SBUV and SAGE in the tropical upper stratosphere, as well up to $50 \%$ differences in ozone on a shorter time scale. Errors in the SAGE retrieval from the climatology used to correct Rayleigh scattering, the beta-angle problem and use of NCEP temperatures are discussed in Wang et al. (1996, 2011); Hassler et al. (2008); McLinden et al. (2009); Remsberg and Lingenfelser (2010).

The above mentioned studies indicate the complexities in using raw data from SBUV and SAGE instruments. Therefore, our approach here is to use the homogenised SBUV and SAGE data sets that have been well documented and are used in published studies. For SBUV, we use SAGE-corrected SBUV ozone profile data from McLinden et al. (2009), which were obtained from ftp://es-ee.tor.ec.gc. ca/pub/SAGE_corrected_SBUV (hereafter "SBUV/SAGE"). They are constructed by correcting the drifts in individual SBUV instruments and inter-SBUV biases using coincident SAGE I and II observations. We also use SAGE ozone profile data from Randel and Wu (2007), which were obtained from ftp://atmos.sparc.sunysb.edu/pub/sparc/ref_clim/ randel/o3data (hereafter "SAGE-based"). These are monthly mean ozone data (in DU km${ }^{-1}$ ) for altitudes up to $50 \mathrm{~km}$, and are derived from a combination of SAGE I - II satellite data and polar ozonesondes for the 1979-2005 time period. For profile comparisons we also use sunrise and sunset measurements from the Halogen Occultation Experiment (HALOE - V19, 1992-2005). Data are included only if the measurement error is less than $100 \%$. Recently identified corrupted HALOE ozone profiles due to a trip angle problem (C. Brühl, personal communication, 2009), are not used. Monthly mean values are calculated only if more than five profiles between $25^{\circ} \mathrm{S}-25^{\circ} \mathrm{N}$ are available for a given month. Due to its shorter time span, detailed analysis of HALOE data is not performed here, though we do use it to compare solar maximum and solar minimum conditions.

\section{Results and discussion}

Figure 1 shows monthly total ozone anomalies from SLIMCAT (runs A_E40, B_EI, C_FIX and D_AFIX) and TOMS/SBUV data averaged between $25^{\circ} \mathrm{S}-25^{\circ} \mathrm{N}$. The normalised $\mathrm{F} 10.7 \mathrm{~cm}$ solar radio fluxes used in our analysis, which are a good proxy for month-to-month and inter-annual solar UV variations, are also shown. The TOMS/SBUV data clearly shows some inter-annual variation, a long-term decrease, variability due to QBO and solar fluxes as well as enhanced ozone loss after the volcanic eruptions. All of the model runs simulate at least part of the long-term ozone decrease and solar-cycle-related variability in the tropical total column. However, model runs with time varying aerosol show more ozone loss after the Mt. Pinatubo eruption in 

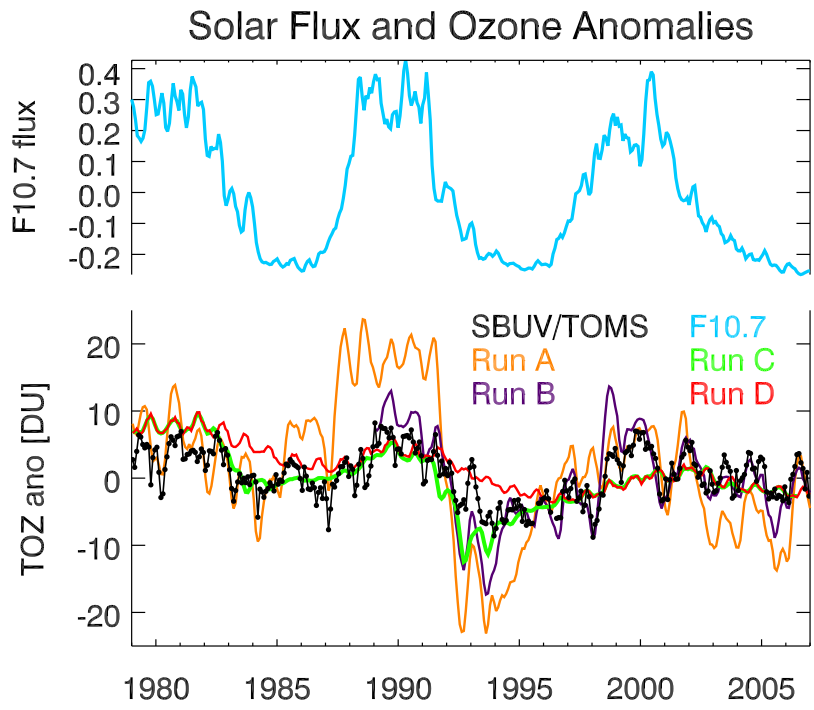

Fig. 1. Comparison of monthly tropical $\left(25^{\circ} \mathrm{S}-25^{\circ} \mathrm{N}\right)$ total ozone anomalies in DU (lower panel) from the v5 SBUV/TOMS merged ozone data set (black line) with results from SLIMCAT runs A_E40 (orange line), B_EI (violet line), C_FIX (green line) and D_AFIX (red line). The normalised F10.7 cm solar flux used in the analysis are shown in upper panel (light blue line).

June 1991 and the model runs with fixed dynamics show very little inter-annual variation.

Among the runs with time-varying dynamics, B_EI shows better agreement with the TOMS/SBUV data than A_E40 from 1989 onwards, the start of the ERA-Interim data. However, some distinct differences between the satellite data and these two model runs (A_E40 and B_EI) are also visible. First, both model runs show more ozone loss after the Mt. Pinatubo eruption, and again agreement is worse in run A_E40. Second, a sudden drop in modelled ozone anomalies after 2001 in run A_E40, associated with the change in meteorological fields, is also visible. Third, during the 1980s larger differences in modelled ozone anomalies from run A_E40 and TOMS/SBUV data are noticeable. Recent total ozone retrieval (v8) from both TOMS and SBUV shows good agreement with the ground-based stations (Labow et al., 2004). Hence irregular differences between TOMS/SBUV data and chemically consistent modelled data indicate time-varying inconsistencies in dynamical fields used for these runs.

Surprisingly, long-term total ozone anomalies from runs C_FIX and D_AFIX agree better with the TOMS/SBUV data. However, similar to runs A_E40 (-20 DU) and B_EI $(-15 \mathrm{DU})$, run C_FIX $(-10 \mathrm{DU})$ also shows more ozone loss after the Mt. Pinatubo eruption than TOMS/SBUV data ( $-6 \mathrm{DU})$. This clearly indicates that model simulations with time varying aerosols overestimate ozone loss after large volcanic eruptions in the presentday atmosphere. This discrepancy seems to be a common problem with many chemical models. Ozone loss in the presence of stratospheric aerosols is controlled by the amount of chlorine activation in the individual model. For example, SPARC (2010, Chapter 8) summarised that after large volcanic eruptions, none out of 18 participating CCMs in the Chemistry-Climate Model Validation Activity (CCMVal-2) could simulate stratospheric ozone changes correctly. Similar findings were reported in WMO $(2007,2011)$ where models overestimated ozone loss in the Southern Hemisphere after the eruption of Mt Pinatubo. As for our model, this is likely due to an overestimation of the chlorine activation enhancement on cold liquid sulfate aerosols. We are not aware of any solar-response-related model studies that provide detailed analysis of ozone loss after large volcanic eruptions.

Anomalies from run D_AFIX shows less ozone variability, except for a long-term decrease (due to changes in halogen loading) and a cleaner "photochemical" solar cycle. The differences between run C_FIX and run D_AFIX reveal the chemical-only ozone loss (without dynamical feedback) after two volcanic eruptions (El Chichón in 1982 and Mt. Pinatubo). Anomalies from run C_FIX minus D_AFIX indicate nearly -3 DU (El Chichón, 1982-1984) and -10 DU (Mt. Pinatubo, 1991-1994) chemical ozone loss after the eruptions. This shows that dynamical variability in both ERA-40 and ERA-Interim analyses is also responsible for more ozone loss in the SLIMCAT simulations.

Figure 2 compares tropical $\left(25^{\circ} \mathrm{S}-25^{\circ} \mathrm{N}\right)$ monthly ozone anomalies from SBUV/SAGE, SAGE-based, HALOE and the SLIMCAT simulations at 4 altitudes. During the mid1990s modelled ozone anomalies from runs A_E40 and B_EI are in reasonable agreement with SBUV/SAGE, SAGE-based and HALOE anomalies. As for total ozone, increases in ozone at $25 \mathrm{~km}$ from run A_E40 in the late 1980s overestimate the observations. Sudden changes in ozone anomalies after 2001 from run A_E40 above $40 \mathrm{~km}$ are distinctly visible. A similar drop in ozone anomalies from run B_EI is noticeable after 1998 at $50 \mathrm{~km}$. One of the key feature in Fig. 2 is that at $40 \mathrm{~km}$ the modelled ozone anomalies from run A_E40 show an increasing trend until 1990 and hence they are consistently lower than SBUV/SAGE or SAGE-based data during the early 1980s. This is most likely due to inhomogeneities in ERA-40 data during 1980s (e.g. see Fig. 6 from Dhomse et al., 2008).

Figure 2 also reveals some additional differences in the TLS. At $25 \mathrm{~km}$, after the Mt. Pinatubo eruption (19921995), both runs A_E40 and B_EI show more ozone loss than the satellite-based data sets. In the lower stratosphere, run C_FIX shows ozone loss only for years 1992-1993, whereas run A_E40 shows more ozone loss even in years 1994-1995 (only during 1994 for run B_EI, see also Fig. 1). Again, this implies that ERA-40 and ERA-Interim meteorology causes more ozone loss in years 1994-1995 than SLIMCAT would have simulated with enhanced aerosols after the Mt. Pinatubo eruption. This also explains the larger modelled ozone solar response in the TLS and is discussed 
(a) Tropical Ozone Anomalies (ppm)
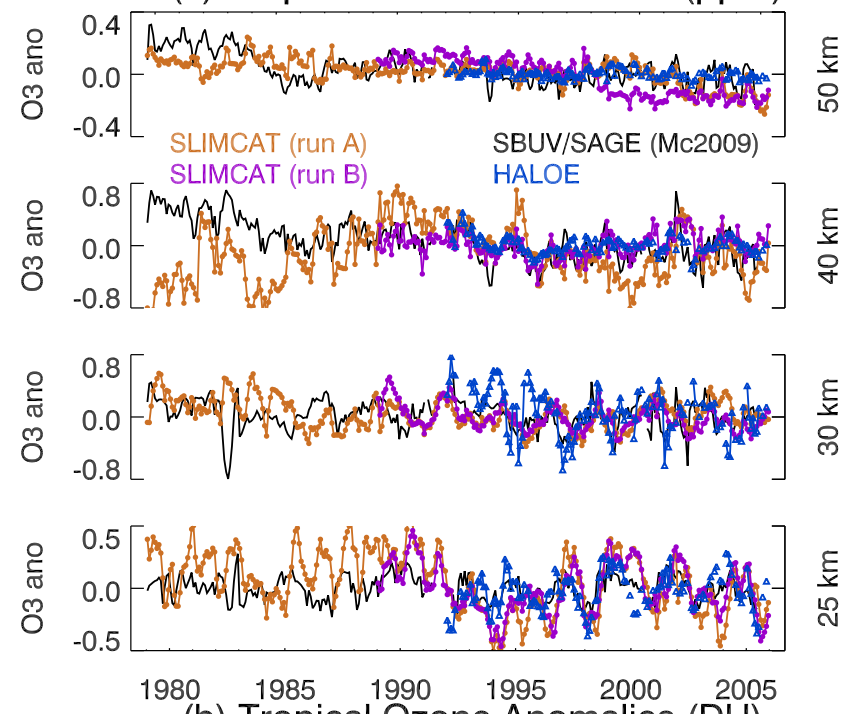

(b) Tropical Ozone Anomalies (DU)
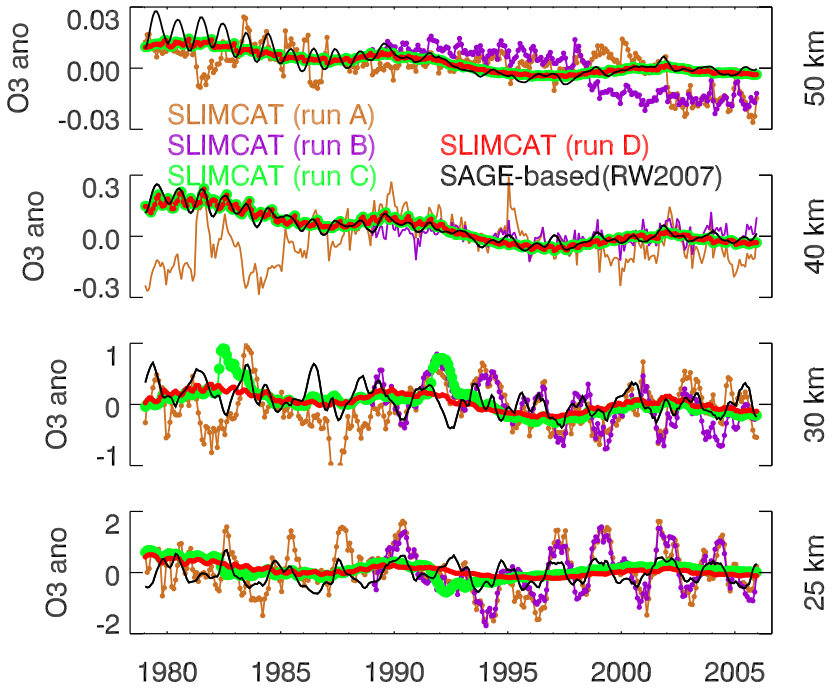

Fig. 2. Comparison of tropical $\left(25^{\circ} \mathrm{S}-25^{\circ} \mathrm{N}\right)$ ozone anomalies from SBUV/SAGE (from McLinden et al., 2009, black line), SAGE-based (from Randel and Wu, 2007, black line), and HALOE (blue line) with model runs A_E40 (orange line), B_EI (violet line), C_FIX (green line), and D_AFIX (red line). Anomalies are shown for $50 \mathrm{~km}$ (top), $40 \mathrm{~km}$ (second from top), $30 \mathrm{~km}$ (third from top), and $25 \mathrm{~km}$ (bottom). Ozone anomalies from HALOE were calculated by combining both sunrise and sunset measurements. Anomalies are shown in ppmv (a) and DU/km (b).

later. In general, HALOE data shows much more variability than SBUV/SAGE or SAGE-based data. This may be due to various smoothing and filtering methods used to create these satellite-based data sets. At higher altitudes the SAGEbased data shows larger ozone decreases than SBUV/SAGE, which is in agreement with Terao and Logan (2007) and Nazaryan et al. (2007). At $30 \mathrm{~km}$, HALOE anomalies show an increase in ozone during 1992-1994 (Remsberg, 2008).
This is likely due to enhanced de-noxification in the middle stratosphere after the volcanic eruption. Runs A_E40, B_EI and C_FIX are also able to simulate these ozone changes. However, the SBUV/SAGE and SAGE-based data do not show this increase. Above $40 \mathrm{~km}$, ozone anomalies from run B_EI are in better agreement with SBUV/SAGE, SAGE-based and HALOE (except after 1998 at $50 \mathrm{~km}$ ).

Again, ozone anomalies from runs C_FIX and D_AFIX show much better agreement with SBUV/SAGE and SAGE-based data than runs A_E40 and B_EI, but have very little inter-annual variability. Both runs clearly indicate the decrease in ozone until 1997 and the levelling off of the ozone decrease following changes in stratospheric chlorine loading. Again, SBUV/SAGE shows more variability compared to the SAGE-based data. Above $40 \mathrm{~km}$, ozone anomalies from runs C_FIX and D_AFIX closely follow the changes in SAGE-based data. This must be due to use of an Equivalent Effective Stratospheric Chlorine (EESC) loading term and the Fortuin and Kelder ozone climatology (Paul et al., 1998) in the creation of the SAGE-based data (Randel and Wu, 2007).

Differences in simulated ozone between runs A_E40 and B_EI are due to differences in the forcing meteorology used for these two runs. Figure $3 \mathrm{a}$ and $\mathrm{b}$ shows the differences in simulated tropical ozone and temperature. During 19982002 large temperature differences are seen between ERA-40 and ERA-Interim at $45-55 \mathrm{~km}$ (ERA-40 colder than ERAInterim). In the upper stratosphere ozone has a short photochemical lifetime and is inversely correlated with temperature due to the strong temperature dependence of the reactions that control the ozone balance. Figure $3 \mathrm{c}$ and $\mathrm{d}$ quantifies this inverse-correlation for the modelled ozone and temperature differences between the two runs for $40 \mathrm{~km}$ and $55 \mathrm{~km}$, respectively. At $40 \mathrm{~km}$ a $1 \mathrm{~K}$ increase in temperature leads to a $2 \%$ decrease in ozone, while at $55 \mathrm{~km}$ a $1 \mathrm{~K}$ increase causes a $1 \% \mathrm{O}_{3}$ decrease. In the lower stratosphere ozone is longer lived and under dynamical control and is positively correlated with the lower stratospheric temperatures (Steinbrecht et al., 2003). The largest differences in modelled ozone (up to $\pm 20 \%$ ) occur in the TLS, where differences in temperature are quite negligible. These large differences in ozone must be due to differences in transport (horizontal as well as vertical) in ERA-40 and ERA-Interim analysis (see also Chipperfield, 2006; Monge-Sanz et al., 2007). Again this shows that although (re)analysis data are realistic, changes in the assimilation system (Dee et al., 2011) can have a significant impact on long-term CTM simulations (Monge-Sanz et al., 2007).

As discussed earlier, stratospheric ozone is strongly influenced by various chemical and dynamical process and quantifying the solar influence is complicated. Therefore, we have performed correlation, composite and regression analyses to check the robustness of the simulated solar response in the tropical stratosphere. Figure 4 shows the lag correlation between tropical ozone anomalies and the QBO $(30 \mathrm{hPa})$, 
(a) dO3 (\%) in tropics [ERA40 - ERA int]
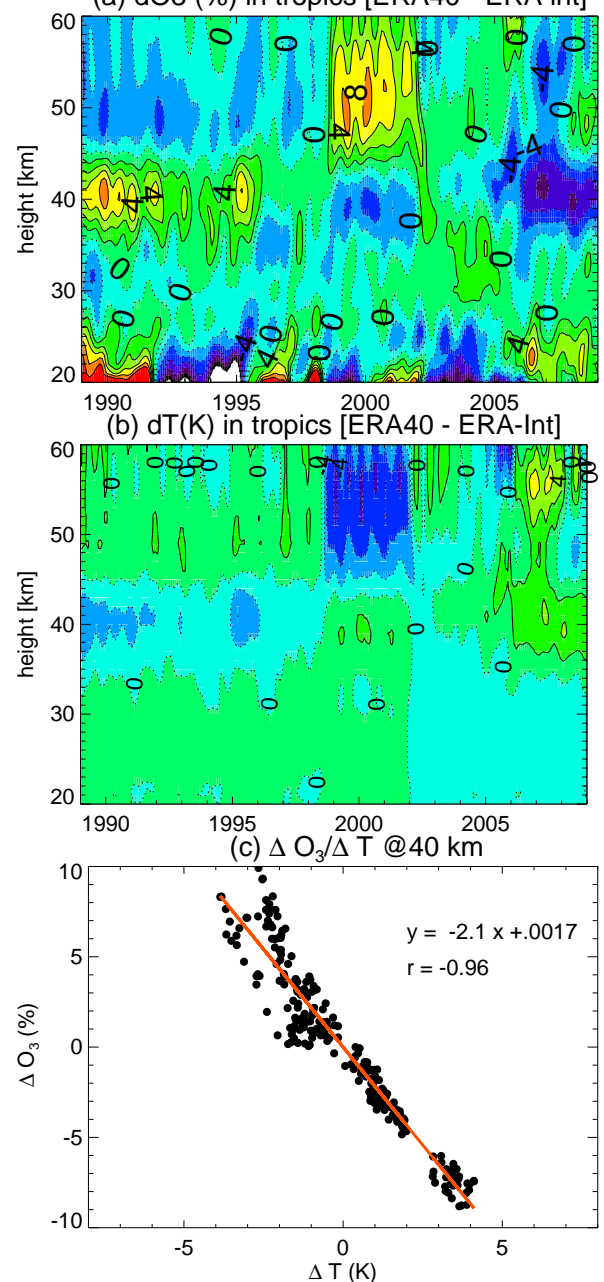

(d) $\Delta \mathrm{O}_{3} / \Delta \mathrm{T} @ 55 \mathrm{~km}$

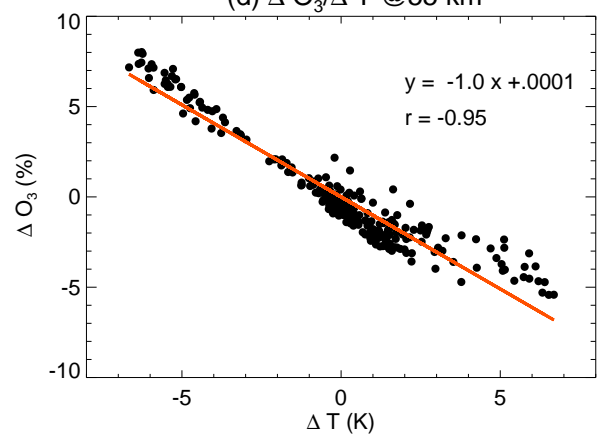

Fig. 3. Differences between tropical $\left(25^{\circ} \mathrm{S}-25^{\circ} \mathrm{N}\right)$ (a) simulated ozone (in \%) and (b) temperature (K). These are calculated as run A_E40 minus run B_EI for ozone and ERA-40/operational minus ERA-Interim for temperatures. Contour intervals are $2 \%$ for $\mathrm{O}_{3}$ and $2 \mathrm{~K}$ for temperature. Positive (green to red colours) and negative (blue to violet colours) differences are shown with solid and dashed lines, respectively. Positive contours in (a), indicate more ozone in run $\mathbf{A} \_\mathbf{E 4 0}$ whereas ones in (b), indicate warmer temperatures in ERA-40. Scatter plots of differences in $\mathrm{O}_{3}(\%)$ and differences in $T$ (K) for run A_E40 minus run B_EI at (c) $40 \mathrm{~km}$ and (d) $55 \mathrm{~km}$.
Southern Oscillation Index (SOI) and F10.7 cm solar flux. The QBO and SOI (Niña 3.4) indices were obtained from the Climate Prediction Centre (CPC) (http://www.cpc.noaa.gov/ data/indices/). Missing SBUV data above $21 \mathrm{~km}$ were interpolated using an harmonic analysis. Correlations are shown for 25 months ( -12 to +12 months).

Generally the QBO - ozone lag-correlation patterns from SLIMCAT and the satellite data (top panels) are quite similar. As the SAGE-based data was constructed using a regression model that included QBO terms it shows the largest correlation (up to +0.7 ) with +6 month lag at $25 \mathrm{~km}$. For the SOI (middle panels) the correlation patterns are somewhat different. Ozone anomalies from runs A_E40 and B_EI show a positive correlation (up to 0.3) in the middle stratosphere, while SBUV/SAGE and SAGE-based data show insignificant correlations throughout the stratosphere. For the F10.7 flux (lower panels) ozone anomalies from both runs A_E40 and B_EI, show larger positive correlations in the TLS stratosphere with a 3-5 month lag. In the lower stratosphere, SBUV/SAGE shows less correlation than SAGE-based data or the model runs. All the data sets show some sort of minimum correlation near $30 \mathrm{~km}$. The largest differences between the data sets occur in the upper stratosphere between 40-50 km. Both SBUV/SAGE and SAGEbased data show a large positive correlation whereas the correlation is much less (or even negative) in the model runs at $50 \mathrm{~km}$.

For the composite analysis, we divide modelled and satellite data into solar maximum and solar minimum months. Months with a normalised F10.7 cm solar flux (shown in Fig. 1) more (less) than $1 \sigma$ from the mean are categorised as solar maximum (minimum) months. For the 1979-2005 time period (runs A_E40, C_FIX, D_AFIX, SBUV/SAGE and SAGE-based data), 75 months were categorised as solar maximum and 80 months as solar minimum. For 19892005 (run B_EI) 44 months each were categorised as solar maximum and minimum. Figure 5 shows the percentage change in ozone for solar maximum minus solar minimum for SBUV/SAGE, SAGE-based and HALOE (from Remsberg, 2008).

Our analysis of SBUV/SAGE and SAGE-based data shows less difference between these data sets than in Hood et al. (2010), particulary around $35 \mathrm{~km}$ where it shows a positive response. This difference in the SBUV analysis with respect to Hood et al. (2010) could be due to the fact we use data from McLinden et al. (2009), which has been corrected using SAGE, and that we process the data on altitude levels. Both runs A_E40 and B_EI show the largest differences in the TLS, where the model shows more ozone during solar maximum than during solar minimum. Minimum ozone differences between solar maximum and solar minimum occur near $30 \mathrm{~km}$, which is in reasonable agreement with most earlier studies (Soukharev and Hood, 2006; Randel and Wu, 2007; Remsberg, 2008). However, the modelled midstratospheric minimum is at a slightly higher altitude $(30 \mathrm{~km})$ 
(a) Lag corr. [O3 vs QBO30]

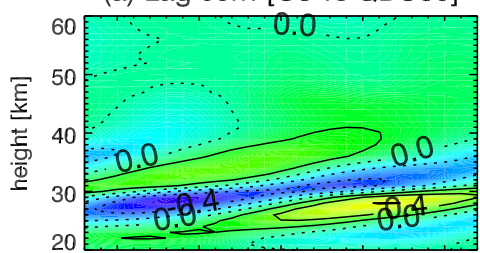

Lag corr. [O3 vs SOI]

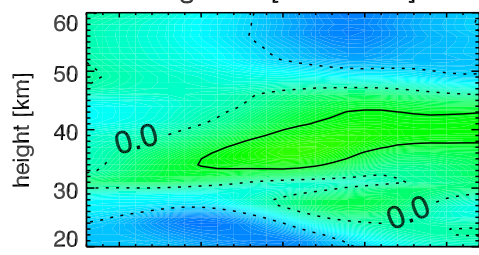

Lag corr. [O3 vs F10 flux]

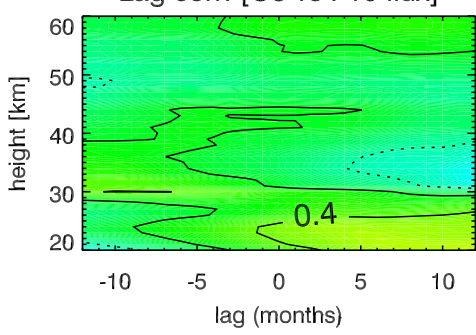

(b) Lag corr. [O3 vs QBO30]

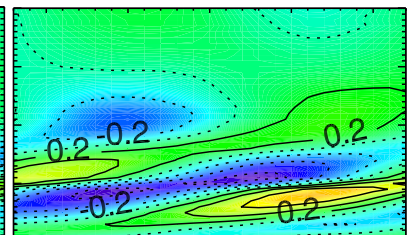

Lag corr. [O3 vs SOI]

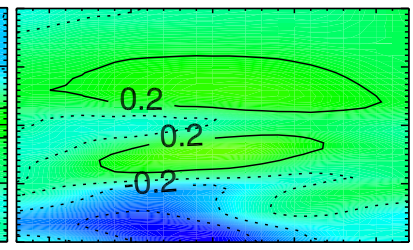

Lag corr. [O3 vs F10 flux]

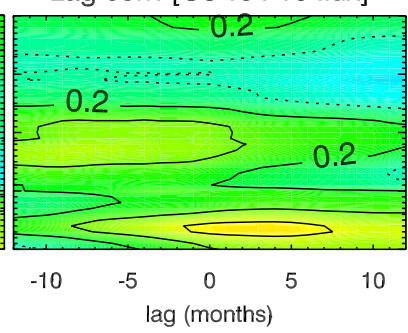

(c) Lag corr. [O3 vs QBO30]

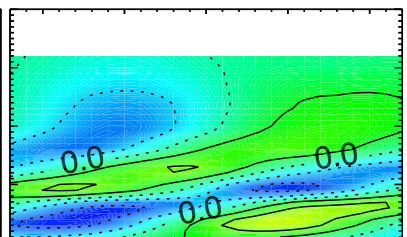

Lag corr. [O3 vs SOI]

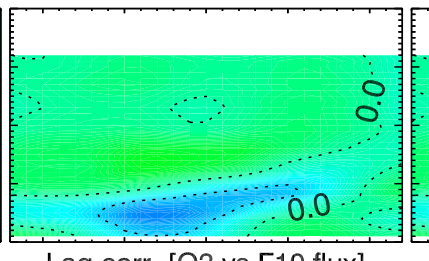

(c) Lag corr. [O3 vs QBO30]

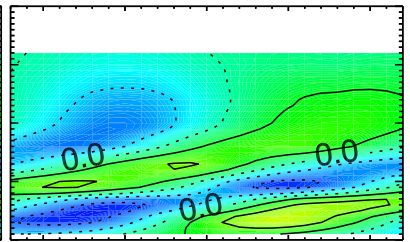

Lag corr. [O3 vs SOI]

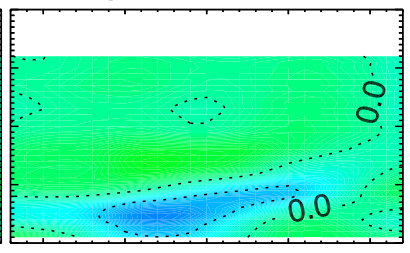

Lag corr. [O3 vs F10 flux]

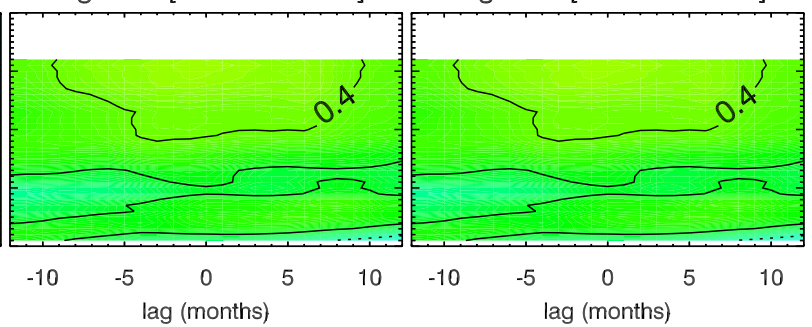

Fig. 4. Lag correlation analysis between tropical ozone anomalies $\left(25^{\circ} \mathrm{S}-25^{\circ} \mathrm{N}\right)$ and zonal wind $(\mathrm{QBO}$ at $30 \mathrm{hPa})$, Southern Oscillation Index (SOI) and F10.7 solar flux from -12 to +12 months in top, middle and bottom rows, respectively. Column (a) shows the lag-correlation between tropical ozone anomalies from run A_E40 and $30 \mathrm{hPa}$ QBO, SOI and F10.7 flux for 1979-2005. Column (b) shows results from B_EI (1989-2005). Column (c) shows results from SBUV/SAGE (1979-2005, from McLinden et al., 2009). Column (d) shows results from SAGE-based (1979-2005, from Randel and Wu, 2007). Positive correlation are shown with solid lines (green and yellow colours), whereas dashed lines indicate negative correlation (blue-violet colours).

than SBUV/SAGE or SAGE-based data $(28 \mathrm{~km})$. Above $35 \mathrm{~km}$ differences between the runs A_E40 and B EI diverge considerably with respect to SBUV/SAGE, SAGE-based and runs C_FIX and D_AFIX, which show up to $4 \%$ ozone difference for solar maximum-minimum months, while runs A_E40 and B_EI (as well as HALOE) show only 1-1.5\% ozone change at these altitudes. Around $50 \mathrm{~km}$, both runs A_E40 and B_EI show negligible ozone difference between solar maximum and solar minimum months, although an increasing difference occurs above this altitude.

Figure 5d shows the solar cycle in ECMWF temperature data calculated by composite analysis for ERA-40 and ERAInterim. In the mid-upper stratosphere both data sets give a maximum response of about $2.5 \mathrm{~K}$, although the peak in ERA-Interim occurs about $10 \mathrm{~km}$ higher altitude than ERA40. The smaller temperature response in ERA-Interim near $40 \mathrm{~km}$ correlates with the larger ozone response here. Similarly, at higher altitudes the larger temperature response in ERA-Interim is coupled to the smaller ozone response. Sudden changes in ERA-40 after 2001 and ERA-Interim after 1998 are not accounted for in the composite analysis of either ozone or temperatures. Hence, some of the differences in solar response between ERA-40 and ERA-Interim (as well as runs A_E40 and BEEI) are due to some abrupt changes in these two data sets as shown in Fig. 3.
Figure $5 \mathrm{c}$ also includes results from the 2-D latitude-height model of Brasseur (1993), as presented by Remsberg (2008, Fig. 12). In the mid-upper stratosphere this model agrees with the results of HALOE and runs AE E40 and B_EI. 2D models have simplified treatments of dynamics but in this region the main driver for the solar response is photochemistry and temperature. The 2-D model will capture the ozone-temperature feedback while our runs CFIX and D_AFIX quantify the solar photochemical response against a background atmosphere with fixed temperatures. The negative temperature-ozone correlation in the mid-upper stratosphere will mean that the positive solar temperature response (e.g. through more ozone heating) will reduce the ozone solar response. This negative feedback means that the solar response diagnosed from runs C_FIX and D_AFIX in the upper stratosphere should be an unrealistic upper limit.

Following earlier studies (e.g. WMO, 2007), we also use a multivariate regression model to quantify the solar response in tropical ozone. The statistical model used here is similar to Dhomse et al. (2006), and has the following form: 
(a) Smax-Smin (\%)

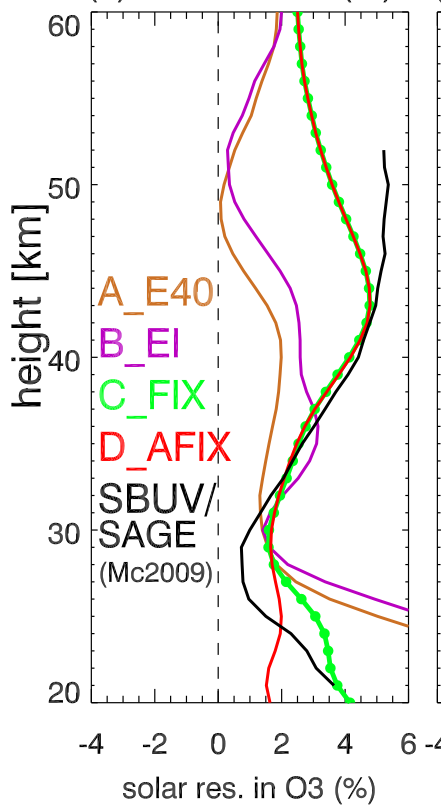

(b) Smax-Smin (\%)

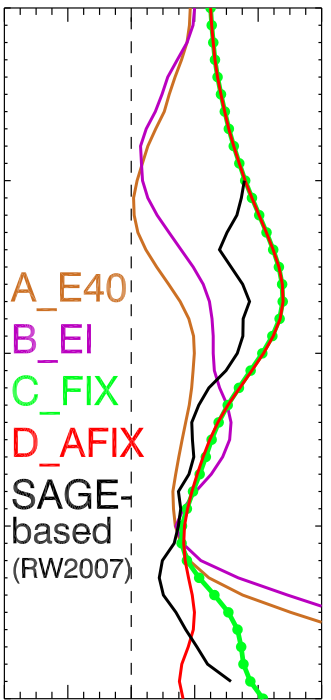

(c) Smax-Smin (\%)

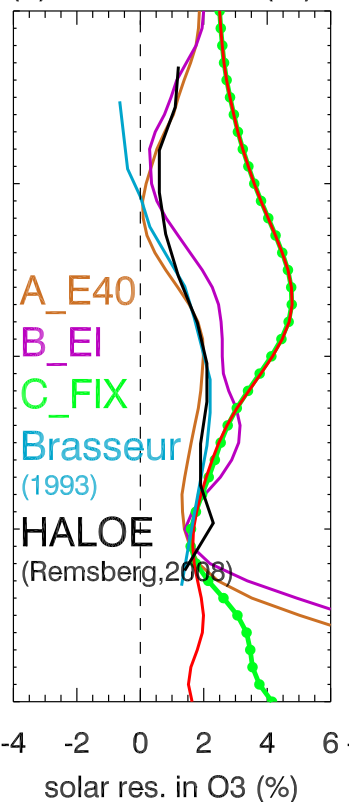

(d) Smax-Smin (K)

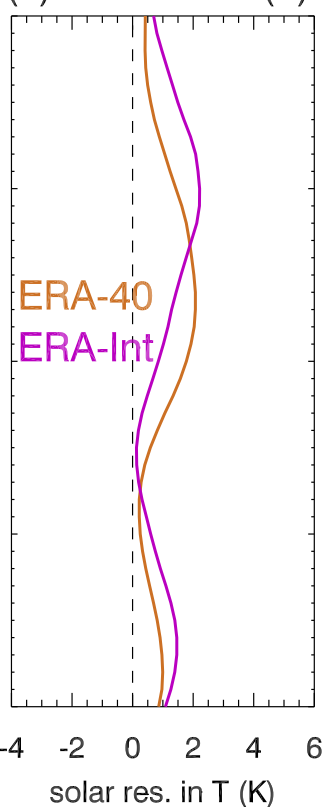

Fig. 5. (a)-(c) Composite analysis (solar max minus solar min) of the simulated ozone response (in \%) from runs A_E40 (orange line), B_EI (violet line), C_FIX (green line) and D_AFIX (red line) in tropics $\left(25^{\circ} \mathrm{S}-25^{\circ} \mathrm{N}\right)$. Also shown is the estimated solar response from (a) SBUV/SAGE (McLinden et al., 2009), (b) SAGE-based (Randel and Wu, 2007), and (c) the Brasseur (1993) 2-D model (light blue) and HALOE data from Fig. 12 of Remsberg (2008) (black). (d) shows the similar composite analysis for temperature (K) from ECMWF ERA-40 and ERA-Interim reanalyses.

$\mathrm{O}_{3}=$ constant $+\mathrm{EESC}+\mathrm{QBO}_{30}+\mathrm{QBO}_{50}+$ aerosols +

solar $+\mathrm{SOI}+$ residuals

where $\mathrm{O}_{3}$ are ozone anomalies for the given month at a given altitude. Monthly mean anomalies are calculated by subtracting 27-yr mean values for a given month. Here we use 12 terms for EESC, 12 terms for stratospheric aerosol loading and 24 terms for the QBO (accounting for both phase and speed of QBO). Eddy heat flux $\left(\overline{v^{\prime} T^{\prime}}\right)$ terms, accounting for the ozone transport to mid-high latitudes (Weber et al., 2003) are not included here, as they may contain some component of solar variability. We use only one term for solar flux variability (F10.7 flux) and one term for SOI. We also apply a Cochrane-Orcutt transformation to the regression equation using an estimate of the auto-correlation with a time lag of one month (Cochrane and Orcutt, 1949). Biases in simulated ozone from runs A_E40 and B_EI, are removed by adding a step function in the regression model after 2001 and 1998, respectively. For run C_FIX, QBO and SOI terms are removed from the regression model. For run D_AFIX, only EESC and solar terms are kept in the regression model. Results from the regression model are shown in Fig. 6. Overall, the estimated solar response follows the results from the correlation and composite analysis. In the TLS, both runs A_E40 and B_EI, show up to $10 \%$ ozone solar response below $25 \mathrm{~km}$, while SBUV, SAGE and run D_AFIX show only up to $3 \%$ response. As mentioned earlier, Marsh and Garcia
(2007) argued that most of the TLS solar response is likely due to ENSO. However, as pointed out by Hood et al. (2010), we also notice that inclusion of ENSO term in our regression model does not show any significant reduction in the magnitude of the solar response in the TLS. So the larger solar response in runs $\mathbf{A} \_\mathbf{E 4 0}$ and $\mathbf{B} \_\mathbf{E I}$ is most probably due to a combination of various process which control the ozone in TLS. First, both runs (A_E40 and B_EI) show more ozone loss due to aerosols (more chlorine activation) during solar minimum months. Second, the dynamical variability during solar minimum years (1994-1995 for ERA-40 and 1994 for ERA-Interim) causes more ozone loss in the SLIMCAT simulations. So, part of the enhanced solar response in TLS in runs A_E40 and B_EI must be associated with the dynamical solar (or decadal) response in the ERA-40 and ERA-Interim data sets.

As mentioned earlier, overestimation of ozone loss in the model gives an almost doubled solar response in run C_FIX compared to run D_AFIX in the TLS. Run D_AFIX agrees better with SBUV/SAGE data than SAGEbased data but is still within the estimated errors. Also, in Fig. 5 run D_AFIX shows a reasonable solar response in the TLS. This shows that part of the lower stratospheric solar response is of photochemical origin and implies that timevarying solar simulations with realistic background meteorological forcing fields (even if they are fixed), are sufficient to simulate the secondary response in the lower stratospheric ozone. 
(a) Solar response (\%)

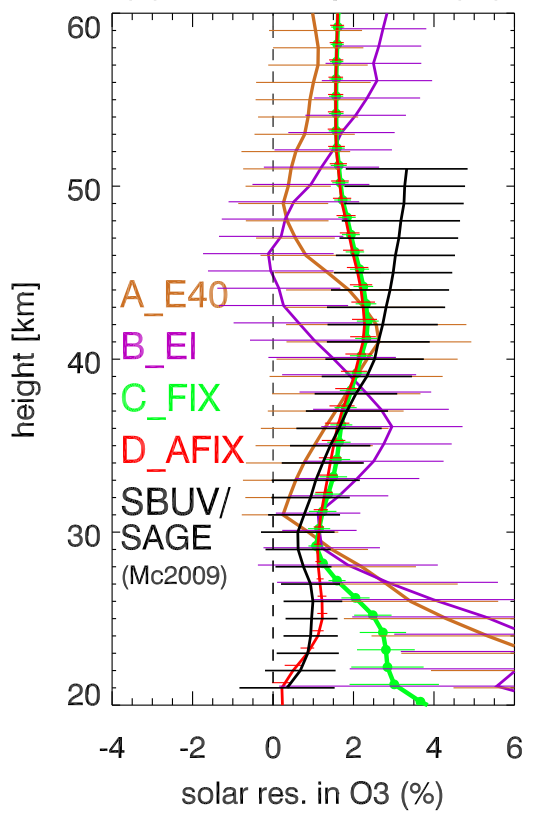

(b) Solar response (\%)

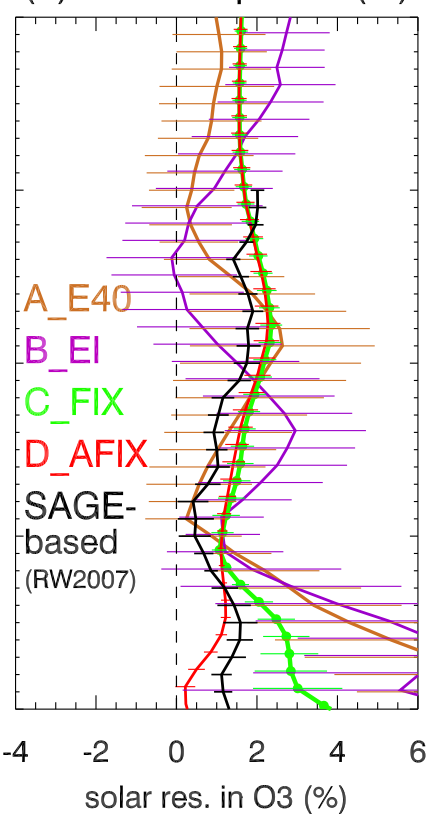

Fig. 6. Solar response in tropical $\left(25^{\circ} \mathrm{S}-25^{\circ} \mathrm{N}\right)$ ozone (in \%) estimated using regression analysis for model runs A_E40, B_EI, C_FIX and D_AFIX compared with observations from (a) SBUV/SAGE (McLinden et al., 2009) and (b) SAGE-based (Randel and Wu, 2007) for 1979-2005. The error bars are $2 \sigma$.

In the middle stratosphere (between $30-45 \mathrm{~km}$ ) runs B_EI, C_FIX and D_AFIX show more reasonable agreement (within error bars) with SBUV/SAGE and SAGE-based data than run A_E40. Both profile and total ozone from run B_EI is in better agreement with SBUV/SAGE, SAGEbased and TOMS/SBUV data. Agreement with the composite analysis in this region adds confidence in the nature of solar response in this region. However, Soukharev and Hood (2006) and Randel and Wu (2007) show negligible (up to $1 \%$ ) solar response between $30-38 \mathrm{~km}$, which is similar to run A_E40. Differences in our analysis compared to Soukharev and Hood (2006) and Randel and Wu (2007) are possibly due to the following reasons. First, neither study includes high stratospheric aerosol loading years and use different approaches to remove the QBO interference. Second, we use satellite-derived data rather than actual retrieved data.

Similar to the correlation and composite analyses, above $45 \mathrm{~km}$ there are significant differences between the estimated solar response using the regression analysis from the model runs, SBUV/SAGE and SAGE-based data sets. Runs A_E40 and B_EI indicate nearly zero solar response at $50 \mathrm{~km}$, which is in agreement with Remsberg and Lingenfelser (2010, Fig. 15). However, runs C_FIX and D_AFIX, SBUV/SAGE and SAGE-based data show up to $4 \%$ solar response in this region, which is similar to Soukharev and Hood (2006) and Randel and Wu (2007). Remsberg and Lingenfelser (2010) argued that these differences are due to larger negative trends in SAGE data in the upper stratosphere for the 1979-2005 period. Randel and Wu (2007) also noted that integrated ozone from SAGE data show larger negative trends than TOMS/SBUV total ozone data.

However, the most striking feature of this analysis is that the solar response from runs C_FIX and D_AFIX show reasonable agreement with SBUV/SAGE and SAGE-based data. It shows that the solar response in upper stratospheric ozone can be reproduced only if unrealistic (i.e. fixed) dynamical and temperature fields are used. The upper stratospheric ozone is highly sensitive to temperature and chlorine loading. There is significant cooling in the upper stratosphere (due to increasing greenhouse gases) and a reversal in chlorine loading (due to the Montreal Protocol). Changes in chlorine are included in runs C_FIX and D_AFIX, which would lead to a long-term trend even with the fixed meteorology.

\section{Summary}

We have used an off-line 3-D chemical transport model to investigate the solar response in tropical stratospheric ozone. Simulated total ozone from the CTM is in reasonable agreement with TOMS/SBUV data for most of long-term and short-term ozone variability. However, some large differences between satellite and modelled total ozone indicate that (a) there are still some inhomogeneities in ERA-40 and ERAInterim reanalyses (especially during the 1980s in ERA-40) and (b) the CTM overestimates the ozone loss during high stratospheric aerosol loading period after the Mt. Pinatubo eruption. Also, total ozone from run B_EI (ERA-Interim) 
shows better agreement with the TOMS/SBUV data than run A_E40 (ERA-40). Therefore, the estimated solar response in studies based on ERA-40 meteorology must be carefully interpreted.

Differences with respect to observations are also seen in the ozone profile from run A_E40 during the 1980s. Although ozone anomalies from run B_EI show better agreement with SBUV/SAGE and SAGE-based data, a sudden drop in ozone above $50 \mathrm{~km}$ in ozone from run B_EI after 1998 is also noticeable. This is driven by temperature changes which are different between ERA-40 and ERA-Interim. Correlation of model ozone and temperature changes shows that a $1 \mathrm{~K}$ temperature decrease leads to a modelled ozone increase of nearly $2 \%$ and $1 \%$ in the middle and upper stratosphere, respectively. In the TLS region, differences in ozone between runs A_E40 and B_EI are due to differences in transport between ERA-40 and ERA-Interim (Monge-Sanz et al., 2007).

We have investigated the modelled ozone solar response using correlation, composite and regression analyses and compared this with satellite-based data sets. The magnitude and shape of the solar response from SBUV/SAGE and SAGE-based data are similar, i.e. minimum solar response near $30 \mathrm{~km}$, which increases in the lower and middle stratosphere. The simulated solar response from all of the model runs seems to be in reasonable agreement with solar response from SBUV/SAGE and SAGE-based data in the lowmid stratosphere. Again the response from run $\mathbf{B} \_$EI agrees somewhat better than run A_E40 with these data sets in this region. However, our modelled solar response averaged between $25^{\circ} \mathrm{S}-25^{\circ} \mathrm{N}$, in the middle stratosphere $(30-38 \mathrm{~km})$ agrees better with Remsberg (2008) (who used HALOE data) and Remsberg and Lingenfelser (2010) (SAGE II: 19922005) than Soukharev and Hood (2006) (HALOE, SAGE and SBUV) and Randel and Wu (2007) (SAGE). The latter two studies show nearly negligible response between $30-38 \mathrm{~km}$. In contrast, our model shows up to $1-2 \%$ ozone response in this region.

The solar response in TLS ozone from runs A_E40 and B.EI appears to be amplified due to enhanced ozone loss during solar minimum months after the volcanic eruptions, other component(s) of 11-yr (or decadal) variability and some inconsistencies (especially early 1990s) in ERA-40 and ERA-Interim data sets. Also, as ozone and temperature are positively correlated in this region, the positive solar response in TLS temperatures implies weaker ascent that will increase the ozone signal (Dhomse et al., 2008; Frame and Gray, 2010). The run (D_AFIX) with constant aerosols and fixed dynamics shows nearly $1 \%$ solar response in TLS while run C.FIX, with time varying aerosols shows nearly $2 \%$ solar response in this region. However, as seen from Figures 1,5 and 6 , oversensitivity to stratospheric aerosols in our simulations results in an aliasing effect of enhanced ozone loss during solar minimum months and hence amplifies the lower stratospheric solar response. These conclusions cannot be compared with Lee and Smith (2003) due to model oversensitivity to stratospheric aerosols.

For the ozone solar response we see the largest observation-model differences in the upper stratosphere, where both SBUV/SAGE and SAGE-based data show a much larger solar response than both runs A_E40 and B_EI. However, we also note that different satellite instruments use different measurement techniques, have retrieval errors and have algorithm limitations (e.g. see Wang et al., 1996; Bharthia et al., 2004). There is also a positive solar response in both ERA-40 and ERA-Interim temperatures (Frame and Gray, 2010; Gray et al., 2009). Randel et al. (2009) and Remsberg (2009) also showed positive signals in radiosonde and HALOE temperatures in the tropical upper stratosphere. Hence, the exact nature of the solar response in upper stratospheric ozone from SBUV and SAGE remains unclear.

Finally, the model run D_AFIX with annually repeating meteorology and constant aerosols is able to simulate most of the solar response seen in SBUV/SAGE, but is slightly lower than SAGE-based data. At lower altitudes this implies that solar response is partially of photochemical origin. This argues that a representation of the QBO may not be necessary to simulate a double-peaked solar response, which is in agreement with Austin et al. (2008) and Schmidt et al. (2010). In the upper stratosphere the photochemically-driven solar response from runs C_FIX and D_AFIX is expected to be an upper limit as it ignores the well-known negative feedback between ozone and temperature. The results imply that the ozone solar response from SBUV and SAGE must be of photochemical origin, but by using ECMWF analyses we have not modelled the solar temperature response correctly.

\section{Conclusions}

Overall our 3-D CTM is able to simulate a double-peakstructured solar response in the tropical stratosphere, but the amplitude and the structure of this response remains as an open issue. Our model simulations show that the TLS ozone solar response is partly of photochemical origin, and QBO and ENSO have very little influence on the ozone solar response in this region. Although our model is more sensitive to aerosol loading, here we have shown that the aliasing effect of volcanic aerosols can lead to amplification of ozone solar response in the TLS. We also show that if there is a positive (negative) solar response in upper stratospheric temperatures, then solar response in ozone should be negative (positive). However, both ERA-40 and ERAInterim data sets have some inhomogeneities, hence better quality (re)analysis data are needed to quantify solar response correctly. Also there is disagreement in the solar response from satellite data sets (SBUV, SAGE, HALOE, SABER), due to retrieval errors and differences in time coverage. A reasonable simulation of observed solar response in upper stratospheric ozone without any dynamical 
feedback, and the disagreement between satellite data sets, indicate that the quantification of solar response still needs further investigation. Use of newly available ozone data from limb/occultation instruments (such as ACE-FTS, GOMOS, MIPAS, SCIAMACHY, SMR, OSIRIS, MLS/AURA) will help us to improve our understanding of the solar response.

Acknowledgements. We thank W. Randel, C. McLinden and E. Remsberg for the SAGE, SBUV and HALOE data. We also thank M. Weber, J. McCormack and an anonymous referee for their time and insightful comments. We also acknowledge use of the ECMWF data which was obtained via the BADC. This work was supported by the NERC SOLCLI project and NCEO.

Edited by: W. Lahoz

\section{References}

Austin, J., Tourpali, K., Rozanov, E., Akiyoshi, H., Bekki, S., Bodeker, G., Brüehl, C., Butchart, N., Chipperfield, M., Deushi, M., Fomichev, V. I., Giorgetta, M. A., Gray, L., Kodera, K., Lott, F., Manzini, E., Marsh, D., Matthes, K., Nagashima, T., Shibata, K., Stolarski, R. S., Struthers, G. H., and Tian, W.: Coupled chemistry climate model simulations of the solar cycle in ozone and temperature, J. Geophys. Res., 113, D11306, doi:10.1029/2007JD009391, 2008.

Bharthia, P., Wellemeyer, C., Taylor, S., Nath, N., and Gopolan, A.: Solar Backscatter (SBUV) Version 8 profile algorithm, in: Proceedings of the Quadrennial Ozone Symposium-2004, edited by: Zerefos, C., 295-296, Athens, Greece, ISBN 960-630-1036, 2004.

Brasseur, G.: The response of the middle atmosphere to long-term and short-term solar variability: A two-dimensional model, J. Geophys. Res., 98, 23079-23090, 1993.

Brasseur, G. and Solomon, S.: Aeronomy of the middle atmosphere, D. Reidel Publishing Company, 1984.

Butchart, N., Charlton-Perez, A. J., Cionni, I., Hardiman, S. C., Haynes, P. H., Krüger, K., Kushner, P. J., Newman, P. A., Osprey, S. M., Perlwitz, J., Sigmond, M., Wang, L., Akiyoshi, H., Austin, J., Bekki, S., Baumgaertner, A., Braesicke, P., Brühl, C., Chipperfield, M., Dameris, M., Dhomse, S., Eyring, V., Garcia, R., Garny, H., Jöckel, P., Lamarque, J., Marchand, M., Michou, M., Morgenstern, O., Nakamura, T., Pawson, S., Plummer, D., Pyle, J., Rozanov, E., Scinocca, J., Shepherd, T. G., Shibata, K., Smale, D., Teyssédre, H., Tian, W., Waugh, D., and Yamashita, Y.: Multimodel climate and variability of the stratosphere, J. Geophys. Res., 116, D05102, doi:10.1029/2010JD014995, 2011.

Callis, L. B., Natarajan, M., and Lambeth, J. D.: Solar-atmospheric coupling by electrons (SOLACE), 3. Comparisons of simulations and observations, 1979-1997, issues and implications, J. Geophys. Res., 106, 7523-7539, 2001.

Chipperfield, M. P.: Multiannual Simulations with a ThreeDimensional Chemical Transport Model, J. Geophys. Res., 104, 1781-1805, 1999.

Chipperfield, M. P.: New Version of the TOMCAT/SLIMCAT OffLine Chemical Transport Model: Intercomparison of Stratospheric Tracer Experiments, Quart. J. Roy. Meteorol. Soc., 132, 1179-1203, 2006.
Chipperfield, M. P. and Jones, R. L.: Relative influences of atmospheric chemistry and transport on Arctic ozone trends, Nature, 400, 551-554, 1999.

Chipperfield, M. P., Gray, L., Kinnersley, J., and Zawodny, J.: A two-dimensional model study of the QBO signal in SAGE II $\mathrm{NO}_{2}$ and $\mathrm{O}_{3}$, Geophys. Res. Lett., 21, 589-592, 1994.

Chipperfield, M. P., Feng, W., and Rex, M.: Arctic Ozone Loss and Climate Sensitivity: Updated Three-Dimensional Model Study, Geophys. Res. Lett., 31, L11813, doi:10.1029/2005GL022674, 2005.

Cochrane, D. and Orcutt, G. H.: Application of least squares regression to relationships containing autocorrelated error terms, J. Am. Stat. Assoc., 44, 32-61, 1949.

Dee, D. P., Uppala, S. M., Simmons, A. J., Berrisford, P., Poli, P., Kobayashi, S., Andrae, U., Balmaseda, M. A., Balsamo, G., Bauer, P., Bechtold, P., Beljaars, A. C. M., van de Berg, L., Bidlot, J., Bormann, N., Delsol, C., Dragani, R., Fuentes, M., Geer, A. J., Haimberger, L., Healy, S., Hersbach, H., Hólm, E. V., Isaksen, L., Kållberg, P., Köhler, M., Matricardi, M., McNally, A. P., Monge-Sanz, B. M., Morcrette, J.-J., Peubey, C., de Rosnay, P., Tavolato, C., Thépaut, J.-N., and Vitart, F.: The ERA-Interim reanalysis: Configuration and performance of the data assimilation system, Quart. J. Roy. Meteorol. Soc., 133, 1972-1990, 2011.

Dhomse, S., Weber, M., Wohltmann, I., Rex, M., and Burrows, J. P.: On the possible causes of recent increases in northern hemispheric total ozone from a statistical analysis of satellite data from 1979 to 2003, Atmos. Chem. Phys., 6, 1165-1180, doi:10.5194/acp-6-1165-2006, 2006.

Dhomse, S., Weber, M., and Burrows, J.: The relationship between tropospheric wave forcing and tropical lower stratospheric water vapor, Atmos. Chem. Phys., 8, 471-480, doi:10.5194/acp-8-4712008, 2008.

Dikty, S., Weber, M., Savigny, C., Sonkaew, T., Rozanov, A., and Burrows, J. P.: Modulations of the 27 day solar rotation signal in stratospheric ozone from Scanning Imaging Absorption Spectrometer for Atmospheric Cartography (SCIAMACHY) (2003-2008), J. Geophys. Res., 115, D00I15, doi:10.1029/2009JD012379, 2010.

Feng, W., Chipperfield, M. P., Dorf, M., Pfeilsticker, K., and Ricaud, P.: Mid-latitude ozone changes: studies with a 3-D CTM forced by ERA-40 analyses, Atmos. Chem. Phys., 7, 2357-2369, doi:10.5194/acp-7-2357-2007, 2007.

Feng, W., Chipperfield, M. P., Davies, S., Mann, G. W., Carslaw, K. S., Dhomse, S., Harvey, L., Randall, C., and Santee, M. L.: Modelling the effect of denitrification on polar ozone depletion for Arctic winter 2004/2005, Atmos. Chem. Phys., 11, 65596573, doi:10.5194/acp-11-6559-2011, 2011.

Frame, T. H. A. and Gray, L. J.: The 11-Yr Solar Cycle in ERA-40 Data: An Update to 2008, J. Climate, 23, 2213-2222, doi:10.1175/2009JCLI3150.1, 2010.

Frith, S., Stolarski, R., and Bharthia, P.: Implications of Version 8 TOMS and SBUV data for long-term trend, in: Proceedings of the Quadrennial Ozone Symposium-2004, edited by: Zerefos, C., Athens, Greece, 65-66, 2004.

Gray, L. J., Rumbold, S. T., and Shine, K. P.: Stratospheric temperature and radiative forcing response to 11 -year solar cycle changes in irradiance and ozone, J. Atmos. Sci., 66, 2402-2417, 2009.

Gray, L. J., Beer, J., M., G., Haigh, J., Lockwood, M., Matthes, K., Cubasch, U., Fleitmann, D., Harrison, G., Hood, L., Luter- 
bacher, J., Meehl, G., Shindell, D., van Geel, B., and White, W.: Solar Influences on Climate, Rev. Geophys., 48, RG4001, doi:10.1029/2009RG000282, 2010.

Haigh, J. D.: The role of stratospheric ozone in modulating the solar radiative forcing of climate, Nature, 370, 544-546, 1994.

Haigh, J. D., Winning, A. R., Toumi, R., and Harder, J. W.: An influence of solar spectral variations on radiative forcing of climate, Nature, 467, 696-699, 2010.

Hassler, B., Bodeker, G. E., and Dameris, M.: Technical Note: A new global database of trace gases and aerosols from multiple sources of high vertical resolution measurements, Atmos. Chem. Phys., 8, 5403-5421, doi:10.5194/acp-8-5403-2008, 2008.

Holton, J. and Tan, H.-C.: The influence of the equatorial quasibiennial oscillation on the global circulation at $50 \mathrm{mb}$, J. Atmos. Sci., 37, 2200-2208, 1980.

Hood, L. L. and Soukharev, B. E.: Solar induced variations of odd nitrogen: Multiple regression analysis of UARS HALOE data, Geophys. Res. Lett., 33, L22805, doi:10.1029/2006GL028122, 2006.

Hood, L. L., Soukharev, B. E., and McCormack, J. P.: Decadal variability of the tropical stratosphere: Secondary influence of the El Niño/Southern Oscillation, J. Geophys. Res., 115, D11113, doi:10.1029/2009JD012291, 2010.

Kodera, K. and Kuroda, Y.: Dynamical response to the solar cycle, J. Geophys. Res., 107(D24), 4749, doi:10.1029/2002JD002224, 2002

Labitzke, K.: On the signal of the 11-year sunspot cycle in the stratosphere and its modulation by the quasibiennial oscillation, J. Atmos. Sol.-Terr. Phys., 66, 1151-1157, doi:10.1016/j.jastp.2004.05.011, 2004.

Labitzke, K. and van Loon, H.: Sunspots, the QBO and the stratospheric temperature in the north polar region, Geophys. Res. Lett., 14, 535-537, 1987.

Labow, G., McPeters, R., and Bharthia, P.: A comparison of TOMS \& SBUV Version 8 total column ozone data with data from ground, in: Proceedings of the Quadrennial Ozone Symposium2004, edited by: Zerefos, C., Athens, Greece, ISBN 960-630103-6, 123-124, 2004.

Lean, J. L., White, O. R., Livingston, W. C., and Picone, J. M.: Variability of a composite chromospheric irradiance index during the 11-year activity and over longer time periods, J. Geophys. Res, 106, 10645-10658, 2001.

Lee, H. and Smith, A. K.: Simulations of the combined effects of solar cycle, quasi-biennial oscillation, and volcanic forcing on the stratospheric ozone changes in recent decades, J. Geophys. Res., 108, 4049, doi:10.1029/2001JD001503, 2003.

Marsh, D. R. and Garcia, R. R.: Attribution of decadal variability in lower-stratospheric tropical ozone, Geophys. Res. Lett., 34, L21807, doi:10.1029/2007GL030935, 2007.

Matthes, K., Langematz, U., Gray, L. L., Kodera, K., and Labitzke, K.: Improved 11-year solar signal in the Freie Universität Berlin Climate Middle Atmosphere Model (FUB-CMAM), J. Geophys. Res., 109, D06101, doi:10.1029/2003JD004012, 2004.

Matthes, K., Garcia, R. R., Kinnison, D. E., Sassi, F., and Walters, S.: Role of the QBO in modulating the influence of the 11 year solar cycle on the atmosphere using constant forcings, J. Geophys. Res., 115, D18110, doi:10.1029/2009JD013020, 2010.

McCormack, J. P., Siskind, D. E., and Hood, L. L.: Solar-QBO interaction and its impact on stratospheric ozone in a zonally aver- aged photochemical transport model of the middle atmosphere, $\mathrm{J}$ Geophys. Res., 112, D16109, doi:10.1029/2006JD008369, 2007.

McCormick, M. P., Zawodny, J., Veiga, R., Larsen, J., and Wang, P.: An Overview Of SAGE I And II Ozone Measurements, Planet. Space Sci., 37, 1567-1586, 1989.

McLinden, C. A., Tegtmeier, S., and Fioletov, V.: Technical Note: A SAGE-corrected SBUV zonal-mean ozone data set, Atmos. Chem. Phys., 9, 7963-7972, doi:10.5194/acp-9-7963-2009, 2009.

Merkel, A. W., Harder, J. W., Marsh, D. R., Smith, A. K., Fontenla, J. M., and Woods, T.: The impact of solar spectral irradiance variability on middle atmospheric ozone, Geophys. Res. Lett., 38, L13802, doi:10.1029/2011GL047561, 2011.

Monge-Sanz, B., Chipperfield, M., Simmons, A. J., and Uppala, S. M.: Mean age of air and transport in a CTM: Comparison of different ECMWF analyses, Geophys. Res. Lett., 34, L04801, doi:10.1029/2006GL028515, 2007.

Nazaryan, H., McCormick, M. P., and Russel III, J. M.: Comparative analysis of SBUV/2 and HALOE ozone profiles and trends, J. Geophys. Res, 112, D10304, doi:10.1029/2006JD007367, 2007.

Paul, J., Fortuin, F., and Kelder, H.: An ozone climatology based on ozonesonde and satellite measurements, J. Geophys. Res., 103, 31709-31734, 1998.

Randel, W. J. and Wu, F.: A stratospheric ozone profile data set for 1979-2005: Variability, trends, and comparisons with column ozone data, J. Geophys. Res., 112, D06313, doi:10.1029/2006JD007339, 2007.

Randel, W. J., Shine, K. P., Austin, J., Barnett, J., Claud, C., Gillett, N. P., Keckhut, P., Langematz, U., Lin, R., Long, C., Mears, C., Miller, A., Nash, J., Seidel, D. J., Thompson, D. W. J., Wu, F., and Yoden, S.: An update of observed stratospheric temperature trends, J. Geophys. Res., 114, D02107, doi:10.1029/2008JD010421, 2009.

Remsberg, E. E. and Lingenfelser, G.: Analysis of SAGE II ozone of the middle and upper stratosphere for its response to a decadal-scale forcing, Atmos. Chem. Phys., 10, 11779-11790, doi:10.5194/acp-10-11779-2010, 2010.

Remsberg, E. E.: On the response of Halogen Occultation Experiment (HALOE) stratospheric ozone and temperature to the 11-year solar cycle forcing, J. Geophys. Res., 113, D22304, doi:10.1029/2008JD010189, 2008.

Remsberg, E. E.: Trends and solar cycle effects in temperature versus altitude from the Halogen Occultation Experiment for the mesosphere and upper stratosphere, J. Geophys. Res., 114, D12303, doi:10.1029/2009JD011897, 2009.

Rex, M., Salawitch, R., von der Gathen, P., Harris, N., Chipperfield, M., and Naujokat, B.: Arctic ozone loss and climate change, Geophys. Res. Lett., 31, doi:10.1029/2003GL018844, 2004.

Russell, J. M., Gordley, L. L., Park, J. H., Drayson, S. R., Hesketh, D. H., Cicerone, R. J., Tuck, A. F., Frederick, J. E., Harries, J. E., and Crutzen, P. J.: The Halogen Occultation Experiment, J. Geophys. Res., 98, 10777-10797, doi:10.1029/93JD00799, 1993.

Salby, M. and Callaghan, P.: Connection between the Solar Cycle and the QBO: The Missing Link, J. Climate, 13, 2652-2662, doi:10.1175/1520-0442, 2000.

Sander, S. P., Friedl, R. R., Golden, D. M., Kurylo, M. J., Moortgat, G. K., Keller-Rudek, H., Wine, P. H., Ravishankara, A. R., Kolb, C. E., Molina, M. J., Finlayson-Pitts, B. J., Huie, R. E., 
and Orkin, V. L.: Chemical Kinetics and Photochemical Data for Use in Atmospheric Studies, JPL Publication 06-2, Jet Propulsion Laboratory, Pasadena, Evaluation Number 15, 2006.

Santee, M. L., MacKenzie, I. A., Manney, G. L., Chipperfield, M. P., Bernath, P., Walker, K. A., Boone, C. D., Froidevaux, L., Livesey, N. J., and Waters, J. W.: A study of stratospheric chlorine partitioning based on new satellite measurements and modeling, J. Geophys. Res, 113, D12307, doi:10.1029/2007JD009057, 2008.

Schmidt, H., Brasseur, G. P., and Giorgetta, M. A.: Solar cycle signal in a general circulation and chemistry model with internally generated quasi-biennial oscillation, J. Geophys. Res., 115, D00I14, doi:10.1029/2009JD012542, 2010.

Sekiyama, T. T., Shibata, K., Deushi, M., Kodera, K., and Lean, J. L.: Recent 22-year simulation using 3-D chemical transport model with reanalysis data, Geophys. Res. Lett., 33, L17812, doi:10.1029/2006GL026711, 2006.

Sinnhuber, B., Weber, M., Amankwah, A., and Burrows, J.: Total ozone during the unusual Antarctic winter of 2002, Geophys. Res. Lett., 30, 1580, doi:10.1029/2002GL016798, 2003.

Soukharev, B. E. and Hood, L. L.: Solar cycle variation of stratospheric ozone: Multiple regression analysis of long-term satellite data sets and comparisons with models, J. Geophys. Res., 111, D20314, doi:10.1029/2006JD007107, 2006.

SPARC: SPARC Assessment of stratospheric aerosol properties (ASAP) SPARC Report No. 4, World Climate Research Programme, WCRP-124,WMO/TD-No.1295, 2006.

SPARC: SPARC Report on the Evaluation of ChemistryClimate Models, World Climate Research Programme, WCRP132,WMO/TD-No.1526, 2010.

Steinbrecht, W., Hassler, B., Claude, H., Winkler, P., and Stolarski, R. S.: Global distribution of total ozone and lower stratospheric temperature variations, Atmos. Chem. Phys., 3, 14211438, doi:10.5194/acp-3-1421-2003, 2003.

Steinbrecht, W., Claude, H., and Winkler, P.: Enhanced upper stratospheric ozone: Sign of recovery or solar cycle effect?, J. Geophys. Res., 109, 6713-6727, 2004.

Strahan, S., Douglass, A., Stolarski, R., Akiyoshi, H., Bekki, S., Braesicke, P., Butchart, N., Chipperfield, M., Cugnet, D., Dhomse, S., Frith, S., Gettelman, A., Hardiman, S., Kinnison, D., Lamarque, J., Mancini, E., Marchand, M., Michou, M., Morgenstern, O., Nakamura, T., Olivié, D., Pawson, S., Pitari, G., Plummer, D., Pyle, J., Scinocca, J., Shepherd, T., Shibata, K., Smale, D., Teyssèdre, H., Tian, W., and Yamashita, Y.: Using transport diagnostics to understand Chemistry Climate Model ozone simulations, J. Geophys. Res., 116, D17302, doi:10.1029/2010JD015360, 2011.
Terao, Y. and Logan, J. A.: Consistency of time series and trends of stratospheric ozone as seen by ozonesondes, SAGE II, HALOE, and SBUV(/2), J. Geophys. Res., 112, D06310, doi:10.1029/2006JD007667, 2007.

Tourpali, K., Zerefos, C. S., Balis, D., and Bais, A. F.: The 11-year solar cycle in stratospheric ozone: Comparison between Umkehr and SBUV v8 and effects on surface erythemal irradiance, J. Geophys. Res., 112, D12306, doi:10.1029/2006JD007760, 2007.

Uppala, S. M., Kållberg, P. W., Simmons, A. J., Andrae, U., Bechtold, V. D. C., Fiorino, M., Gibson, J. K., Haseler, J., Hernandez, A., Kelly, G. A., Li, X., Onogi, K., Saarinen, S., Sokka, N., Allan, R. P., Andersson, E., Arpe, K., Balmaseda, M. A., Beljaars, A. C. M., Berg, L. V. D., Bidlot, J., Bormann, N., Caires, S., Chevallier, F., Dethof, A., Dragosavac, M., Fisher, M., Fuentes, M., Hagemann, S., Hólm, E., Hoskins, B. J., Isaksen, L., Janssen, P. A. E. M., Jenne, R., Mcnally, A. P., Mahfouf, J.-F., Morcrette, J.-J., Rayner, N. A., Saunders, R. W., Simon, P., Sterl, A., Trenberth, K. E., Untch, A., Vasiljevic, D., Viterbo, P., and Woollen, J.: The ERA-40 re-analysis, Quart. J. Roy. Meteorol. Soc., 131, 2961-3012, doi:10.1256/qj.04.176, 2005.

Wang, H. J., Cunnold, D. M., and Bao, X.: A critical analysis of Stratospheric Aerosol and Gas Experiment ozone trends, J. Geophys. Res., 101, 12495-12514, 1996.

Wang, H. J., Froidevaux, L., Anderson, J., Schwartz, M., Fuller, R., Bernath, P., Zawodny, J. M., Thomason, L. W., Pawson, S., and Rienecker, M.: Long term stratospheric ozone record obtained by merging $\mathrm{O}_{3}$ profiles from different satellites, SPARC/WMO Ozone Trend Workshop, Geneva, Switzerland, available at: http://igaco-o3.fmi.fi/VDO/presentations_ 2011/datasets/WS_2011_Wang.pdf (last access: 25 November 2011), 2011.

Weber, M., Dhomse, S., Wittrock, F., Richter, A., Sinnhuber, B., and Burrows, J.: Dynamical control of NH and SH winter/spring total ozone from GOME observations in 1995-2002, Geophys. Res. Lett., 30, 1583, doi:10.1029/2002GL016799, 2003.

WMO: Scientific Assessment of Ozone Depletion: 2006, Global Ozone Research and Monitoring Project Report 50, World Meteorological Organization, Geneva, 2007.

WMO: Scientific Assessment of Ozone Depletion: 2010, Global Ozone Research and Monitoring Project Report 52, World Meteorological Organization, Geneva, 2011. 